\title{
Reduced Vesicular Storage of Dopamine Causes Progressive Nigrostriatal Neurodegeneration
}

\author{
W. Michael Caudle, ${ }^{1,2}$ Jason R. Richardson, ${ }^{1,2,3}$ Min Z. Wang, ${ }^{1,2}$ Tonya N. Taylor, ${ }^{1,2}$ Thomas S. Guillot, ${ }^{1,2}$ \\ Alison L. McCormack, ${ }^{4}$ Rebecca E. Colebrooke, ${ }^{5}$ Donato A. Di Monte, ${ }^{4}$ Piers C. Emson, ${ }^{5}$ and Gary W. Miller ${ }^{1,2}$ \\ ${ }^{1}$ Center for Neurodegenerative Disease, ${ }^{2}$ Department of Environmental and Occupational Health, Rollins School of Public Health, Emory University, \\ Atlanta, Georgia 30322, ${ }^{3}$ Department of Environmental and Occupational Medicine, University of Medicine and Dentistry-New Jersey/Robert Wood \\ Johnson Medical School and Environmental and Occupational Health Sciences Institute, Piscataway, New Jersey 08854, ${ }^{4}$ The Parkinson's Institute, \\ Sunnyvale, California 94089, and ${ }^{5}$ The Babraham Institute, Neurobiology Programme, Babraham, Cambridge CB2 4AT, United Kingdom
}

The vesicular monoamine transporter 2 (VMAT2; SLC18A2) is responsible for packaging dopamine into vesicles for subsequent release and has been suggested to serve a neuroprotective role in the dopamine system. Here, we show that mice that express $\sim 5 \%$ of normal VMAT2 (VMAT2 LO) display age-associated nigrostriatal dopamine dysfunction that ultimately results in neurodegeneration. Elevated cysteinyl adducts to L-DOPA and DOPAC are seen early and are followed by increased striatal protein carbonyl and 3-nitrotyrosine formation. These changes were associated with decreased striatal dopamine and decreased expression of the dopamine transporter and tyrosine hydroxylase. Furthermore, we observed an increase in $\alpha$-synuclein immunoreactivity and accumulation and neurodegeneration in the substantia nigra pars compacta in aged VMAT2 LO mice. Thus, VMAT2 LO animals display nigrostriatal degeneration that begins in the terminal fields and progresses to eventual loss of the cell bodies, $\alpha$-synuclein accumulation, and an L-DOPA responsive behavioral deficit, replicating many of the key aspects of Parkinson's disease. These data suggest that mishandling of dopamine via reduced VMAT2 expression is, in and of itself, sufficient to cause dopamine-mediated toxicity and neurodegeneration in the nigrostriatal dopamine system. In addition, the altered dopamine homeostasis resulting from reduced VMAT2 function may be conducive to pathogenic mechanisms induced by genetic or environmental factors thought to be involved in Parkinson's disease.

Key words: Parkinson's disease; vesicular monoamine transporter 2; dopamine; neurodegeneration; dopamine transporter; tyrosine hydroxylase

\section{Introduction}

The vesicular monoamine transporter 2 (VMAT2; SLC18A2) resides intracellularly on small synaptic and dense core vesicles, sequesters cytosolic dopamine (DA) for subsequent release, and is a key regulator of dopamine homeostasis (Liu and Edwards, 1997). VMAT2 is a target of several agents, including reserpine, tetrabenazine, amphetamine, and methamphetamine (German et al., 1981; Fumagalli et al., 1999; Jones et al., 1999) as well as the dopaminergic neurotoxin 1-methyl-4-phenylpyridinium (MPP+) (Liu et al., 1992b). VMAT2 is a member of the toxin-extruding antiporter gene family, which includes some bacterial antibiotic resistance genes (Schuldiner et al., 1995; Yelin and Schuldiner, 1995). The function of

Received Jan. 24, 2007; revised May 25, 2007; accepted June 21, 2007.

This work was supported by the Emory Collaborative Center for Parkinson's Disease Environmental Research U54ES012068 and American Parkinson's Disease Association (G.W.M.), and National Institutes of Health Grants T32ES012870 (W.M.C.), F32ES013457 and R21ES013828 (J.R.R.), ES010806 and ES12077 (D.A.D.), an Environmental Protection Agency Science to Achieve Results Fellowship (T.S.G.), Parkinson's Disease (United Kingdom) Grant 4039 (P.C.E.), and a Medical Research Council Cooperative Award in Science and Enginineering studentship with Sanofi-Aventis (R.E.C.). We thank Dr. Randy Hall for his critical reading and helpful comments regarding the preparation of this manuscript.

Correspondence should be addressed to Gary W. Miller, Center for Neurodegenerative Disease, Emory University Whitehead Biomedical Research Building, Room 505K, 615 Michael Street, Atlanta, GA 30322. E-mail: gary.miller@emory.edu.

DOI:10.1523/JNEUROSCI.0319-07.2007

Copyright $\odot 2007$ Society for Neuroscience $\quad 0270-6474 / 07 / 278138-11 \$ 15.00 / 0$
VMAT2 is coupled to a proton ATPase in the vesicular membrane. It has been hypothesized that VMAT2 evolved to serve a parallel toxin extruding function in eukaryotes. Indeed, the cloning of VMAT1 [formerly CGAT (chromaffin granule amine transporter) (Liu et al., 1992a,b)] and VMAT2 [formerly SVAT (synaptic vesicle amine transporter), MAT (monoamine transporter) (Erickson et al., 1992)] was the result of a series of elegant experiments that focused on the ability to genetically transfer resistance to the neurotoxin MPP+ from chromaffin cells to cells that were sensitive to MPP+ (Liu et al., 1992b). Furthermore, reduction in VMAT2 results in an increased sensitivity to 1-methyl-4-phenyl-1,2,3,6-tetrahydropyridine and methamphetamine toxicity in mice (Takahashi et al., 1997; Gainetdinov et al., 1998; Fumagalli et al., 1999; Staal et al., 2000; Mooslehner et al., 2001). Thus, proper functioning of VMAT2 influences dopamine homeostasis and vulnerability to various toxicants.

Several studies have shown accumulation of cytosolic dopamine to be neurotoxic through the generation of reactive oxygen species (ROS) and quinones (Hastings et al., 1996a,b; Hastings and Zigmond, 1997; Montine et al., 1997; Rabinovic et al., 2000). Furthermore, generation of ROS has been suggested to be a key mediator in the pathophysiology of Parkinson's disease (PD) (Jenner, 2003). This suggests that VMAT2 may be an important determinant in dopamine-related toxicity and reduction in its 
expression or function could adversely affect dopamine neuron survival and function. In support of this concept, a recent report by Glatt et al. (2006) demonstrated a gain of function VMAT2 haplotype in humans was protective against PD. These studies suggest that perturbation of VMAT2 could lead to dopaminergic damage and potentially contribute to the pathogenic process in PD.

Previously, generation of transgenic mice targeting VMAT2 resulted in mice that expressed 50\% normal VMAT2 (heterozygous), as well as a complete deletion (knock-out) (Fon et al., 1997; Takahashi et al., 1997; Wang et al., 1997). Although the heterozygous VMAT2 mice thrive, the knock-out animals only survive for 1-3 d after birth. We recently generated a transgenic mouse line expressing 5\% normal VMAT2 levels [low expressor (VMAT2 LO)] (Mooslehner et al., 2001; Colebrooke et al., 2006). Unlike mice with a complete gene deletion of the gene, VMAT2 LO mice survive into adulthood, providing a unique opportunity to examine the impact of disruption of vesicular function on the aging dopamine system.

\section{Materials and Methods}

Animals. Four-month-old male and female mice heterozygous for the VMAT2 gene were obtained from the original colony at the Babraham Institute (Mooslehner et al., 2001). Briefly, the mouse VMAT2 locus was cloned from the $129 / \mathrm{Sv}$ genomic library and a $2.2 \mathrm{~kb} P v u \mathrm{II}$ fragment from the third intron of the VMAT2 gene and then cloned into the bluntended NotI site of this construct. The targeting vector was introduced into 129/Ola CGR 8.8 embryonic stem (ES) cells and injected into blastocytes of C57BL/6 mice. Highly chimeric males were bred with C57BL/6 females, and genotype was confirmed by Southern blot analysis. A recent report brought to our attention the $\mathrm{C} 57 \mathrm{BL} / 6$ inbred strain of mice originally used to establish the VMAT2 LO mice contained a spontaneous chromosomal deletion spanning the $\alpha$-synuclein gene locus (Specht and Schoepfer, 2001), which was confirmed in the original strain (Mooslehner et al., 2001; Patel et al., 2003; Colebrooke et al., 2006). Through diligent breeding, we eliminated all traces of this mutation from our strain of mice and routinely verify the presence of $\alpha$-synuclein by Southern blot analysis. This report represents the first data on VMAT2 LO mice with a normal $\alpha$-synuclein background. All mice were generated through redundant breeding of mice that were heterozygous for the VMAT2 allele and wild type (WT) for the $\alpha$-synuclein allele. The genotype of all mice was confirmed by Southern blot analysis of DNA extracted from tail samples. All procedures were conducted in accordance with the National Institutes of Health Guide for Care and Use of Laboratory Animals and previously approved by the Institutional Animal Care and Use Committee at Emory University.

Western immunoblotting analysis. Western blots were used to quantify the amount of dopamine transporter (DAT), manganese superoxide dismutase (MnSOD), 3-nitrotyrosine (3-NT), tyrosine hydroxylase (TH), VMAT2, and $\alpha$-tubulin present in samples of striatal tissue and were performed as described previously (Caudle et al., 2006). Briefly, striata samples were homogenized and subjected to PAGE and electrophoretically transferred to polyvinylidene difluoride membranes. Nonspecific sites were blocked in $7.5 \%$ nonfat dry milk in Tris-buffered saline, and membranes were then incubated overnight in a monoclonal antibody to the N terminus of DAT (1:5000; Chemicon, Temecula, CA) (Miller et al., 1997). DAT antibody binding was detected using a goat anti-rat horseradish peroxidase secondary antibody $(1: 10,000)$ and enhanced chemiluminescence. The luminescence signal was captured on an Alpha Innotech (San Leandro, CA) Fluorochem imaging system and stored as a digital image. Densitometric analysis was performed and calibrated to coblotted dilutional standards of pooled striata from all control samples. Membranes were stripped for $15 \mathrm{~min}$ at room temperature with Pierce (Rockford, IL) Stripping Buffer and sequentially reprobed with MnSOD (1:1000; BD Biosciences, Franklin Lakes, NJ), 3-NT (1:200; Upstate Biotechnology, Charlottesville, VA), TH (1:1000; Chemicon), and VMAT2 (1:1000; Chemicon) antibody. $\alpha$-Tubulin blots were used to ensure equal protein loading across samples.
Immunohistochemical analysis. Tissue staining was performed as described previously (Miller et al., 1997, 1999b; Caudle et al., 2006). Briefly, VMAT2 wild-type and hypomorph mice were perfused transcardially with $4 \%$ paraformaldehyde. Brains were removed and processed for frozen or paraffin-embedded sections. Sections were incubated with a monoclonal anti-DAT (1:750; Chemicon), monoclonal anti- $\alpha$-synuclein antibody (1:1000; BD Biosciences) or a polyclonal anti-TH antibody (1:2000; Chemicon) overnight and then incubated in a biotinylated goat ant-rat secondary antibody for $1 \mathrm{~h}$ at room temperature. Visualization was performed using $0.03 \% 3,3^{\prime}$-diaminobenzidine (DAB) for $1 \mathrm{~min}$ at room temperature.

Tissue staining and cell counts were performed as described previously (McCormack et al., 2002; Reveron et al., 2002). Briefly, midbrain blocks from VMAT2 wild type and hypomorph mice were immersion fixed in $4 \%$ paraformaldehyde and serially sectioned at $40 \mu \mathrm{m}$. Sections were incubated with a polyclonal anti-TH antibody (1:1000; Pel Freez Biologicals, Rogers, AR) overnight and then incubated in a biotinylated goat anti-rabbit secondary antibody for $1 \mathrm{~h}$ at room temperature. Visualization was performed using DAB for 3 min at room temperature. After $\mathrm{DAB}$, all sections were counterstained in $0.5 \%$ cresyl violet, dehydrated, and coverslipped. Neurons were counted using the optical fractionator method, and the substantia nigra pars compacta was delineated using previously described criteria (West et al., 1991; Chan et al., 1997). After delineation at low magnification, every sixth section was sampled at higher magnification using the Cast grid system (Olympus, Albertslund, Denmark).

Vesicular $\left[{ }^{3} \mathrm{H}\right]$ dopamine uptake. Whole brains from 2-month-old VMAT2 WT and LO mice were prepared as described previously (Staal et al., 2000). Whole brains were homogenized in buffer (4 mM HEPES, 0.32 M sucrose, $\mathrm{pH}$ 7.4) Homogenates were centrifuged at $1000 \times g$ for 10 $\mathrm{min}$, and the resulting supernatant was centrifuged at $20,000 \times g$ for 20 $\mathrm{min}$. The resulting pellet was resuspended in $1.6 \mathrm{ml}$ of $0.32 \mathrm{M}$ sucrose before being transferred to a glass/Teflon homogenizer containing $6.4 \mathrm{ml}$ of water and subjected to 10 up-and-down strokes by hand. All contents of the homogenizer were then poured into a tube containing $1 \mathrm{ml}$ each of $250 \mathrm{~mm}$ HEPES and $1 \mathrm{~m}$ potassium tartrate and inverted to mix. The mixture was then centrifuged at $20,000 \times g$ for $20 \mathrm{~min}$, and the resulting supernatant was placed in an ultracentrifuge tube and spun at $120,000 \times$ $g$ for $2 \mathrm{~h}$. Vesicles were resuspended in $1.8 \mathrm{ml}$ of buffer ( $100 \mathrm{~mm}$ potassium tartrate, 25 mm HEPES, 0.1 mм EDTA, 0.05 mm EGTA, $1.7 \mathrm{~mm}$ ascorbate, $\mathrm{pH}$ 7.4). Uptake assays used $300 \mu \mathrm{l}$ of vesicle solution for each dopamine concentration, with $2 \%\left[{ }^{3} \mathrm{H}\right]$ dopamine as a tracer and $10 \mu \mathrm{M}$ tetrabenazine (Sigma, St. Louis, $\mathrm{MO}$ ) to define specific uptake. Samples were incubated for $10 \mathrm{~min}$ at $30^{\circ} \mathrm{C}$ followed by the addition of $\left[{ }^{3} \mathrm{H}\right]$ dopamine and further incubation for $5 \mathrm{~min}$ at $30^{\circ} \mathrm{C}$. The assay was terminated by addition of $5 \mathrm{ml}$ of ice-cold assay buffer before filtration through $0.5 \%$ polyethylenamine-soaked Whatman GF/F filters (Brandel, Gaithersburg, MD). Filters were then placed in scintillation fluid and counted using a Beckman LS6500 (Beckman Instruments, Fullerton, CA). Velocity was expressed as $\mathrm{pmol}$ dopamine/mg of protein/min, and the kinetic parameters, $K_{\mathrm{M}}$ and $V_{\mathrm{MAX}}$, were calculated by nonlinear regression using GraphPad (San Diego, CA) Prism 4.0 software.

Locomotor activity. Mice were placed in polycarbonate locomotor boxes $(25.4 \times 50.8 \times 25.4 \mathrm{~cm})$, and horizontal distance was quantified over time using Noldus Ethovision 3.0 (Noldus Information Technology, Wageningen, The Netherlands). General locomotion for aged VMAT2 WT and LO mice was observed for a total of $2 \mathrm{~h}$. The first $30 \mathrm{~min}$ were considered the habituation period to ensure stabilization of the horizontal activity signal. VMAT2 WT and LO mice were administered a single dose of $15 \mathrm{mg} / \mathrm{kg}$ L-DOPA [ $20 \mathrm{~min}$ before L-DOPA administration, animals were given $12.5 \mathrm{mg} / \mathrm{kg}$ benserazide (Sigma)] and then placed in the recording chambers $30 \mathrm{~min}$ later and recorded for $2 \mathrm{~h}$.

Synaptosomal $\left[{ }^{3} \mathrm{H}\right]$ dopamine uptake. Dopamine uptake studies were performed as described previously (Caudle et al., 2006). Briefly, crude synaptosomes were prepared from fresh striatal tissue and incubated in assay buffer ( $4 \mathrm{~mm}$ Tris, $6.25 \mathrm{~mm}$ HEPES, $120 \mathrm{~mm} \mathrm{NaCl}, 5 \mathrm{~mm} \mathrm{KCl}, 1.2$ mм CaCl2, $1.2 \mathrm{~mm} \mathrm{MgSO}_{4}, 0.6 \mathrm{~mm}$ ascorbic acid, $5.5 \mathrm{~mm}$ glucose, $10 \mu \mathrm{M}$ pargyline, $\mathrm{pH} 7.4)$ containing a saturating concentration of dopamine (1 $\mu \mathrm{M}$ final concentration) and a tracer amount of $\left[{ }^{3} \mathrm{H}\right]$ dopamine $(20 \mathrm{nM})$. 
Uptake was allowed to proceed for $3 \mathrm{~min}$ at $37^{\circ} \mathrm{C}$ and then terminated by the addition of ice-cold buffer and rapid vacuum filtration over GF/B filter paper using a Brandel harvester. Filters were washed twice with buffer, allowed to air dry, and placed in scintillation vials containing $8 \mathrm{ml}$ of Econoscint (Fisher Scientific, Pittsburgh, PA) for scintillation counting. Uptake rates were calculated as specific uptake (total uptakenonspecific uptake), with nonspecific uptake defined by the inclusion of $10 \mu \mathrm{M}$ nomifensine. After determination of protein concentrations (Bradford, 1976), uptake rates were calculated as $\mathrm{pmol} / \mathrm{min}-\mathrm{mg}$ protein and expressed as raw values.

Synaptosomal $\left[{ }^{3} \mathrm{H}\right]$ WIN 35,428 binding. Determination of $\left[{ }^{3} \mathrm{H}\right]$ WIN 35,428 binding to DAT was performed as described previously (Caudle et al., 2006). Binding studies with crude striatal synaptosomes were conducted with a single concentration ( $10 \mathrm{nM}$ ) of $\left[{ }^{3} \mathrm{H}\right]$ WIN 35,428 in $25 \mathrm{~mm}$ sodium phosphate buffer ( $125 \mathrm{~mm} \mathrm{NaCl}, 5 \mathrm{~mm} \mathrm{KCl}, \mathrm{pH} 7.4)$ for $1 \mathrm{~h}$ at $4^{\circ} \mathrm{C}$ in 96 -well plates. Incubations were terminated by rapid vacuum filtration onto GF/B filter plates, and radioactivity was determined by liquid scintillation counting. Nonspecific binding was determined by the inclusion of $10 \mu \mathrm{M}$ nomifensine, and specific binding was calculated as the total binding (incubated without $10 \mu \mathrm{M}$ nomifensine) minus nonspecific binding (incubated with nomifensine). After determination of protein concentrations (Bradford, 1976), binding to DAT was calculated as $\mathrm{fmol} / \mathrm{mg}$ protein and expressed as raw values.

Protein carbonyl detection. For determination of protein carbonyl levels in tissue, striatum from one hemisphere was rapidly dissected and frozen on liquid nitrogen. Tissue was homogenized in $0.32 \mathrm{M}$ sucrose supplemented with protease inhibitors (aprotinin, leupeptin, pepstatin). The homogenate was centrifuged for $5 \mathrm{~min}$ at $2200 \times g$ at $4^{\circ} \mathrm{C}$. The supernatant was removed and centrifuged for $45 \mathrm{~min}$ at $20,800 \times g$ at $4^{\circ} \mathrm{C}$. The pellet was resuspended in $0.32 \mathrm{M}$ sucrose, and protein concentrations were determined using the Bradford protein assay (Bradford, 1976). Protein carbonyl levels were determined using dot blots and the Oxyblot Protein Detection Kit (Chemicon) according to manufacturer protocol. Briefly, in this protocol, protein carbonyls are derivatized to 2,4-dinitrophenylhydrazone (DNP) by reaction with 2,4-dinitrophenylhydrazine. DNP-derivatized protein samples were analyzed using dot blots and antibodies against DNP.

Detection of neurodegeneration. Fluoro-Jade B (Histo-Chem, Jefferson, AR) and silver staining (FD Neurosilver kit; FD NeuroTechnologies, Ellicott City, MD) for degenerating neurons was performed according to the manufacturer protocols. Mice were transcardially perfused with $4 \%$ paraformaldehyde, and $40 \mu \mathrm{m}$ sections through the substantia nigra and ventral tegmental area were cut on a freezing microtome.

HPLC determination of dopamine and metabolites, cysteinyl adducts, and glutathione. HPLC-electrochemical (EC) analysis of neurochemistry was performed as described previously (Richardson and Miller, 2004; Caudle et al., 2006). Briefly, dissected left striata were sonicated in $0.1 \mathrm{M}$ perchloric acid containing $347 \mu \mathrm{M}$ sodium bisulfite and $134 \mu \mathrm{M}$ EDTA. Homogenates were centrifuged at $15,000 \times g$ for $10 \mathrm{~min}$ at $4^{\circ} \mathrm{C}$, and the supernatant was removed and filtered through a $0.22 \mu \mathrm{m}$ filter by centrifugation at $15,000 \times g$ for $10 \mathrm{~min}$. The supernatants were then analyzed for levels of DA, DOPAC, and homovanillic acid (HVA). Levels were measured using HPLC with an eight-channel coulometric electrode array (ESA Coularray; ESA Laboratories, Chelmsford, MA). Quantification was made by reference to calibration curves made with individual standards.

Determination of cysteinyl-catechols, cysteinyl-dopamine (cys-DA), cysteinyl-DOPA (cys-DOPA), and cysteinyl-DOPAC (cys-DOPAC) was determined as described by Fornstedt-Wallin and Bergh (1995) with modifications. Briefly, dissected left striata were sonicated in $0.1 \mathrm{M}$ perchloric acid containing $347 \mu \mathrm{M}$ sodium bisulfite and $134 \mu \mathrm{M}$ EDTA. Homogenates were centrifuged at $15,000 \times g$ for $10 \mathrm{~min}$ at $4^{\circ} \mathrm{C}$, and the supernatant was removed and filtered through a $0.22 \mu \mathrm{m}$ filter by centrifugation at $15,000 \times g$ for $10 \mathrm{~min}$. The supernatants were then analyzed for levels of cys-DA, cys-DOPA, and cys-DOPAC. All analysis was performed on a Waters (Milford, MA) Alliance HPLC equipped with a Waters 2465 electrochemical detector set at an oxidizing potential of +0.65 V. Analytes were separated with a Waters XTerra C18 column (5 $\mu \mathrm{m} ; 150 \times 4.6 \mathrm{~mm})$ maintained at $32^{\circ} \mathrm{C}$. The mobile phase was MD-TM mobile phase (ESA Laboratories) containing $2 \mathrm{~mm} \mathrm{NaCl}$ and adjusted to $\mathrm{pH} 2.1$ with concentrated $\mathrm{HCl}$. Quantification was made by reference to
A.
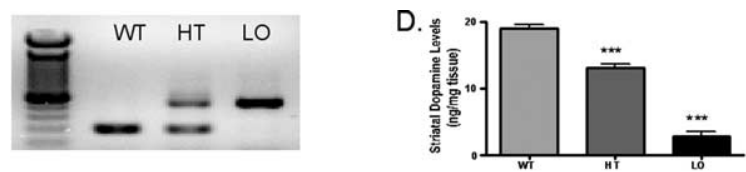

B.

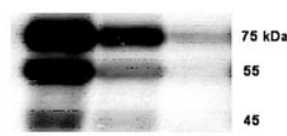

E.

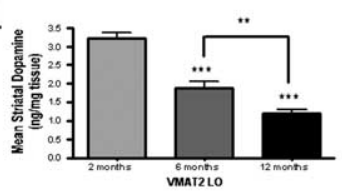

C.

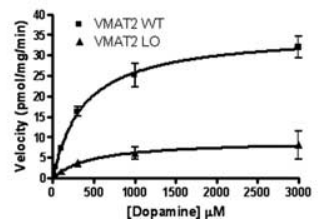

$\mathrm{F}$.

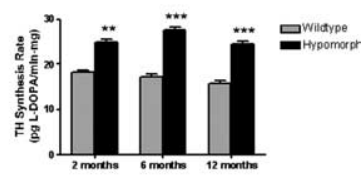

Figure 1. Characterization of VMAT2 LO mice. $A$, Southern blot analysis of mouse genomic DNA. $\boldsymbol{B}$, Representative Western blot analysis of striatal synaptosomes from 2-month-old VMAT2 WT, HT, and $\mathrm{LO}$ mice. $\mathrm{C},\left[{ }^{3} \mathrm{H}\right]$ Dopamine uptake in purified vesicles from 2-month-old VMAT2 WT and LO whole brain. $V_{\text {MAX }}: W T, 35.6 ; L 0,9.2 ; K_{M}: W T, 0.377 ; L 0,0.482$. Results are presented as the mean $V_{\text {MAX }}$ (pmol/mg/min) \pm SEM for three animals per genotype. $D$, HPLC analysis of striatal dopamine levels of 2-month-old VMAT2 WT, HT, and LO mice. E, HPLC analysis of striatal dopamine levels in aged VMAT2 LO mice. $\boldsymbol{F}$, Analysis of tyrosine hydroxylase synthesis rate in VMAT2 WT and LO mice after injection of $100 \mathrm{mg} / \mathrm{kg}$ of the aromatic acid decarboxylase inhibitor NSD 1015. HPLC results are presented as the mean raw values $(\mathrm{ng} / \mathrm{mg}$ tissue) \pm SEM for four animals per age group. ${ }^{* *} p<0.01 ;{ }^{* * *} p<0.001$.

calibration curves constructed with pure ( $>98 \%$ ) cys-DA, cys-DOPA, and cys-DOPAC standards obtained from the National Institute of Mental Health Chemical Repository (Research Triangle Institute International, Research Triangle Park, NC).

Analysis of glutathione levels was performed by HPLC with fluorescence detection as described previously (Jones et al., 2004). Briefly, fresh striatal tissue was collected and immediately transferred to a microcentrifuge tube containing ice-cold $5 \%(\mathrm{w} / \mathrm{v})$ perchloric acid, $0.2 \mathrm{~m}$ boric acid, and $10 \mu \mathrm{M}$ $\gamma$-Glu-Glu as internal standard. Tissue was immediately homogenized and stored at $-80^{\circ} \mathrm{C}$ ( $<1$ month) before further processing to form $N$-dansyl derivatives and analysis by HPLC with fluorescence detection. The stability of glutathione has been validated under these storage conditions. Glutathione was quantified by integration relative to the internal standard (Jones, 2002), and the total glutathione measurement was determined as the sum of glutathione and its disulfide forms. The redox potential of glutathione (Eh) was calculated according to the Nernst equation: $E \mathrm{~h}=E 0+(\mathrm{RT} /$ $\mathrm{nF})^{*} \ln ([\mathrm{GSSG}] /[\mathrm{GSH}] 2)$ (Watson et al., 2003).

Tyrosine hydroxylase activity. Tyrosine hydroxylase activity was measured as described by Carlsson et al. (1972). Briefly, mice were injected intraperitoneally with $100 \mathrm{mg} / \mathrm{ml}$ of the aromatic acid decarboxylase inhibitor NSD 1015 and killed $1 \mathrm{~h}$ later. Striata were removed bilaterally and prepared as described above for HPLC-EC. Tyrosine hydroxylase activity was determined by measuring L-DOPA.

Reverse transcription-PCR analysis of DAT. RNA was isolated from ventral mesencephalon. RNA was isolated using the Qiagen (Valencia, CA) RNEasy Lipid Tissue Mini Kit according to instructions by the manufacturer. RNA concentration was determined by standard spectrophotometric analysis, and $1 \mu \mathrm{g}$ of total RNA was used for cDNA synthesis with the Applied Biosystems (Bedford, MA) High Capacity cDNA Archive kit according to the manufacturer protocol.

Statistical analysis. All statistical analysis was performed on raw data for each treatment group by one-way ANOVA or Student's $t$ test. Post hoc analysis was performed using Student-Newman-Keuls test. Statistical significance is reported at the $p<0.05$ level.

\section{Results}

Southern blot analysis of VMAT2 WT, heterozygote (HT), and low expressors shows the WT and the LO band corresponding to the predicted base pairs. The HT contains both bands (Fig. 1A). 
A.

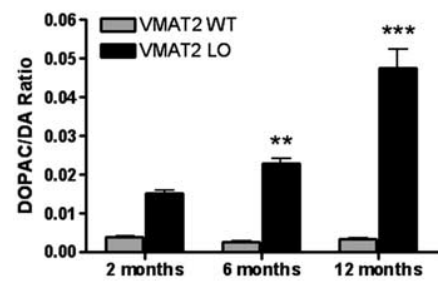

B.

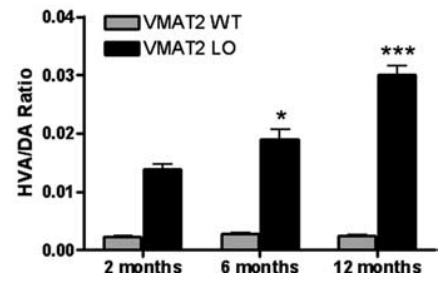

Figure 2. Ratio of DOPAC/DA and HVA/DA in the striatum of VMAT2 WT and LO mice at 2,6, and 12 months of age. $A, B$, Results represent mean ratios of raw values ( $\mathrm{ng} / \mathrm{mg}$ tissue) $\pm \mathrm{SEM}$ for four animals per genotype at each age. ${ }^{*} p<0.05 ;{ }^{* *} p<0.01 ;{ }^{* * *} p<0.001$.

VMAT2 expression in striatum of 2-month-old mice showed 50 and $95 \%$ reductions in the VMAT2 HT and LO mice, respectively, compared with WT (Fig. 1B). In Figure 1C, a significant reduction in VMAT2-mediated $\left[{ }^{3} \mathrm{H}\right]$ dopamine uptake in LO mice compared with WT littermates is seen. Although dopamine levels are normal in striata of WT mice, these levels are reduced by $35 \%$ in $\mathrm{HT}$ and $85 \%$ in LO mice (Fig. 1 D). A concomitant reduction in the dopamine metabolites, DOPAC and HVA, was also observed in the VMAT2 HT and LO mice at 2 months of age (data not shown).

Further examination of striatal dopamine levels was performed in the VMAT2 LO mice at 2, 6, and 12 months of age revealed an age-dependent decline in dopamine $(42 \%$ at 6 months and $64 \%$ at 12 months, compared with 2-month-old VMAT2 LO) (Fig. $1 E$ ). Furthermore, VMAT2 LO mice exhibit an age-associated and genotype-dependent increase in tyrosine hydroxylase activity (Fig. $1 F$ ), as well as an increase in the DOPAC/DA and HVA/DA ratio (Fig. $2 A, B$ ) in the striatum. As a result of striatal dopamine depletion, VMAT2 LO mice exhibit a $40 \%$ decrease in locomotor behavior at 2, 6, and 12 months and a $60 \%$ decrease at 18 months of age compared with VMAT2 WT (Fig. 3A). These locomotor deficits were ameliorated after a single administration of $15 \mathrm{mg} / \mathrm{kg}$ L-DOPA (Fig. 3B).

The presence of free cysteinyl-catechols in dopamine-rich brain regions is thought to reflect the oxidation of cytosolic dopamine and its metabolites (Graham, 1978). Free cysteinylcatechols were measured in the striatum of VMAT2 WT and LO mice at 2 and 12 months. Free cysteinyl-DOPAC and L-DOPA were significantly increased in the VMAT2 LO mice by approximately twofold and threefold, respectively (Fig. 4A,B). To further assess the impact of dopamine mishandling, we examined the generation of ROS in the form of nitrated and carbonylated proteins in the striatum of aged VMAT2 WT and LO mice. As seen in Figure 5A, an increase in the production of protein carbonyls of VMAT2 LO mice was seen at $12(60 \%)$ and $18(55 \%)$ months of age. In addition, VMAT2 LO mice exhibited an increase in 3-nitrotyrosine immunoreactivity at $12(180 \%)$ and $18(170 \%)$ months of age (Fig. $5 B$ ). Analysis of protein carbonyls and 3-nitrotyrosine in the frontal cortex revealed no change in either marker in the VMAT2 LO mice at any age (data not shown).

Additional analysis of markers of oxidative stress in the striatum
A.

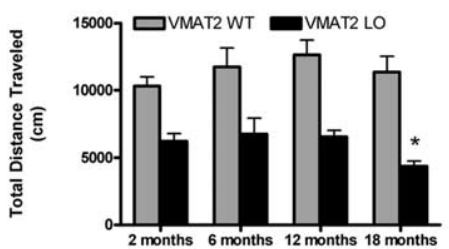

B.

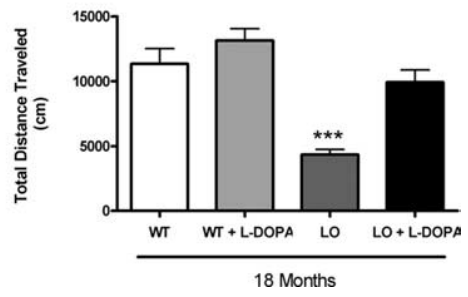

Figure 3. Locomotor activity of VMAT2 WT and LO mice. A, General locomotor activity of VMAT2 WT and L0 mice was measured at 2, 6, 12, and 18 months of age. $\boldsymbol{B}$, Locomotor activity was recorded in 18 -month-old VMAT2 WT and $L 0$ mice for $2 \mathrm{~h}$ before and after administration of $15 \mathrm{mg} / \mathrm{kg} \mathrm{L-DOPA}$ plus benserazide. Locomotor activity results are presented as the mean distance traveled $(\mathrm{cm}) \pm$ SEM for $8-10$ mice per genotype. ${ }^{*} p<0.05 ;{ }^{* * *} p<0.001$.
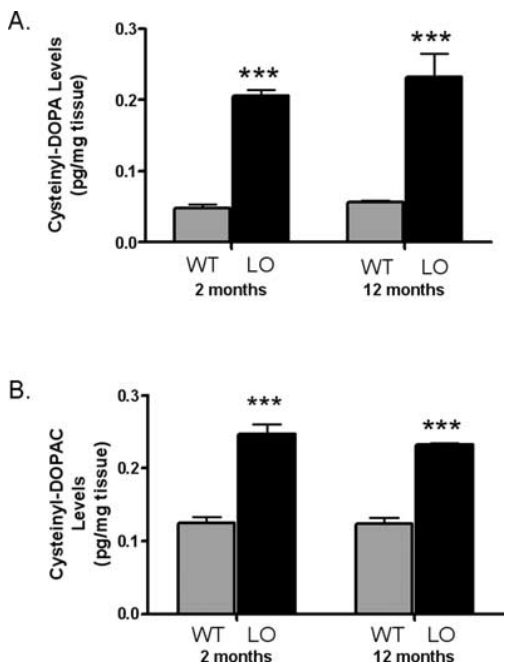

Figure 4. Evidence of oxidative stress in aged VMAT2 LO mice. A, HPLC-EC analysis of cysteinyl-DOPA adducts in aged VMAT2 mice. Striatal samples from VMAT2 WT and LO mice at 2 and 12 months of age were used for HPLC determination of cysteinyl-DOPA adducts. A significant increase in cysteinyl-DOPA adducts was seen in VMAT2 LO mice at 2 and 12 months of age compared with their age-matched controls. Results represent the mean raw values $(\mathrm{pg} / \mathrm{mg}$ tissue) \pm SEM for four animals per genotype at each age. ${ }^{* * *} p<0.001$. B, HPLC-EC analysis of cysteinyl-DOPAC adducts in aged VMAT2 mice. Striatal samples from VMAT2 WT and LO mice at 2 and 12 months of age were used for HPLC determination of cysteinyl-DOPAC adducts. A significant increase in cysteinyl-DOPAC adducts was seen in VMAT2 L 0 mice at 2 and 12 months of age compared with their age-matched controls. Results represent the mean raw values (pg/mg tissue) \pm SEM for four animals per genotype at each age. ${ }^{* * *} p<0.001$.

of aged VMAT2 LO mice focused on changes in the level and oxidation of glutathione (GSH), as well as expression of MnSOD. As seen in Figure 6A, no significant change was seen in GSH redox states in the striatum of VMAT2 LO at 2 and 18 months of age compared with their age-matched controls. A significant decrease in total levels of striatal GSH was seen in the VMAT2 WT and LO animals at 18 months of age compared with WT and LO animals at 2 months of age (Fig. $6 \mathrm{~B}$ ). A significant decrease in striatal MnSOD expression was observed in the VMAT2 LO animals at 18 months of age compared with their age-matched controls. No change was seen in MnSOD levels in VMAT2 WT mice (Fig. 6C). 
A.

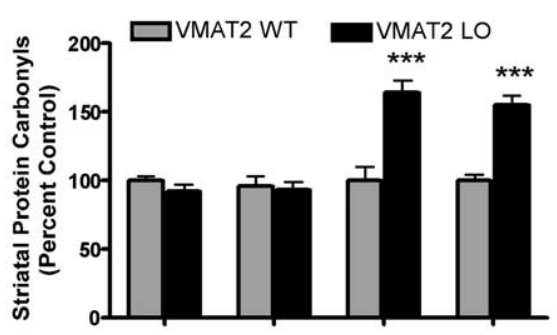

2 months 6 months 12 months 18 months

B.

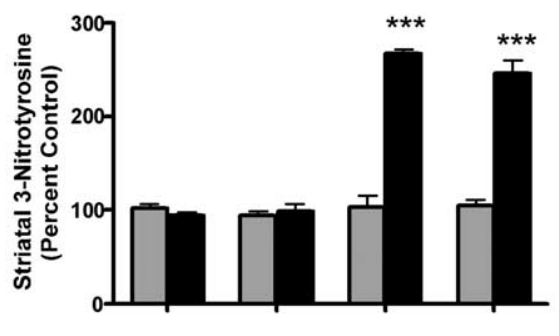

2 months 6 months 12 months 18 months

C.

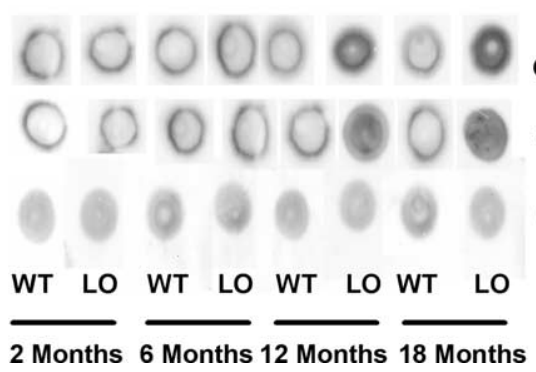

Figure 5. A, Dot blot analysis of striatal protein carbonyls. Striatal samples from VMAT2 WT and $\mathrm{L} 0$ mice at 2, 6, 12, and 18 months were analyzed for protein carbonyl levels. No change was seen in carbonyl levels in VMAT2 WT mice at any time point. A significant increase in carbonyls was observed in the VMAT2 LO mice at 12 and 18 months, compared with WT. Columns represent the percentage change from control. Results represent the mean \pm SEM for four animals per genotype at each age. ${ }^{* * *} p<0.001$. B, Western blot analysis of striatal samples for 3-NT. Striatal samples from VMAT2 WT and L0 mice at 2, 6, 12, and 18 months were analyzed for 3-nitrotyrosine levels. No change was seen in 3-NT levels in VMAT2 WT mice at any time point. A significant increase in 3-NT was observed in the VMAT2 L0 mice at 12 and 18 months, compared with WT. C, Representative dot blots corresponding to each age and genotype. Columns represent the percentage change from control. Results represent the mean \pm SEM for four animals per genotype at each age. ${ }^{* *} p<0.001$.

To determine whether altered VMAT2 expression affects dopamine terminal function, we examined striatal DAT immunoreactivity, $\left[{ }^{3} \mathrm{H}\right]$ WIN 35,428 binding, and $\left[{ }^{3} \mathrm{H}\right]$ dopamine uptake over a range of ages. Immunohistological analyses of striatal DAT revealed a dramatic and progressive decline in DAT immunoreactivity in the VMAT2 LO mice throughout their lifespan (Figs. $7 A, 8)$. As shown by immunoblotting, no changes in DAT levels were observed between WT and LO mice at 2 months of age; however, by 6 months, a $30 \%$ reduction in DAT was apparent in the VMAT2 LO mice. Moreover, DAT levels continued to decline in an age-dependent manner; at 12 months, levels were $54 \%$ of WT mice, and at 18 months, levels had decreased to 60\% (Fig. $10 \mathrm{~A})$. To further assess the loss of DAT, binding assays were performed in isolated striatal synaptosomes using $\left[{ }^{3} \mathrm{H}\right]$ WIN
A.
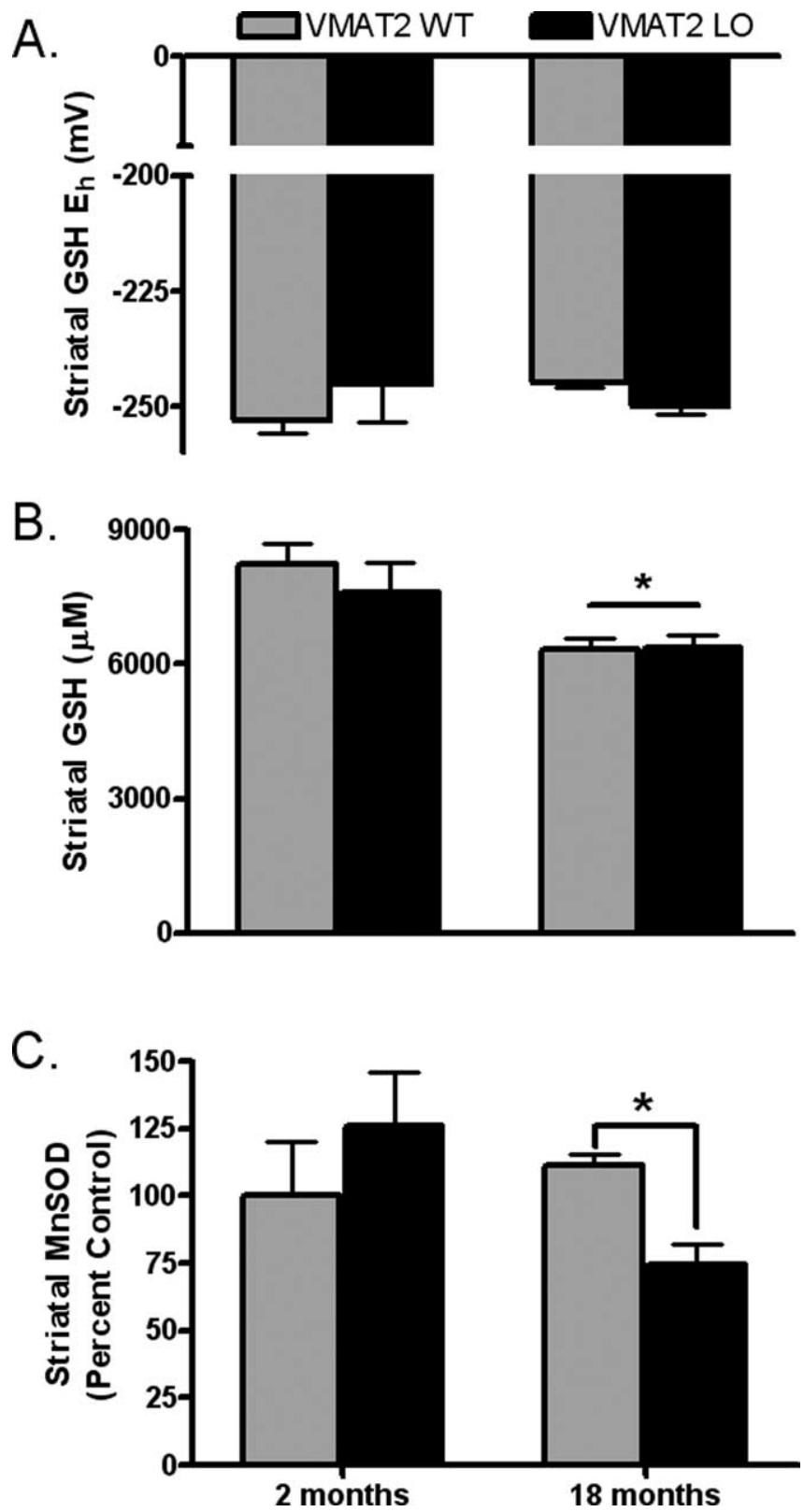

Figure 6. Analysis of glutathione and MnSOD in aged VMAT2 mice. A, HPLC-UV analysis of GSH redox potentials in aged VMAT2 mice. Striatal samples from VMAT2 WT and LO mice at 2 and 18 months of age were used for determination of GSH redox potentials. No significant change was seen in redox states in VMAT2 LO at 2 and 18 months of age compared with their age-matched controls. Results represent the mean raw values of $E_{\mathrm{h}}(\mathrm{mV}) \pm \mathrm{SEM}$ for four animals per genotype at each age. $\boldsymbol{B}$, HPLC-UV analysis of GSH concentrations in aged VMAT2 mice. Striatal samples from VMAT2 WT and L0 mice at 2 and 18 months of age were used for determination of GSH concentrations. A significant decrease in GSH was seen in the VMAT2 WT and $L 0$ animals at 18 months of age compared with WT and $L 0$ animals at 2 months of age. Results represent the mean raw values $(\mu \mathrm{M}) \pm S E M$ for four animals per genotype at each age. ${ }^{*} p<0.05$. C, Western blot analysis of striatal samples for MnSOD. Striatal samples from VMAT2 WT and LO mice at 2 and 18 months were analyzed for MnSOD levels. A significant decrease was seen in the VMAT2 LO animals at 18 months of age compared with their age-matched controls. No change was seen in MnSOD levels in VMAT2 WT mice. Columns represent the percentage change from control. Results represent the mean \pm SEM for four animals per genotype at each age. ${ }^{*} p<0.05$.

35,428 . DAT binding was reduced by 30,52 , and $62 \%$ in VMAT2 LO mice at 6,12 , and 18 months, respectively. In addition, a concomitant reduction $(34,57$, and $66 \%$ at 6,12 , and 18 months, respectively) in DAT-mediated $\left[{ }^{3} \mathrm{H}\right]$ dopamine uptake was also 


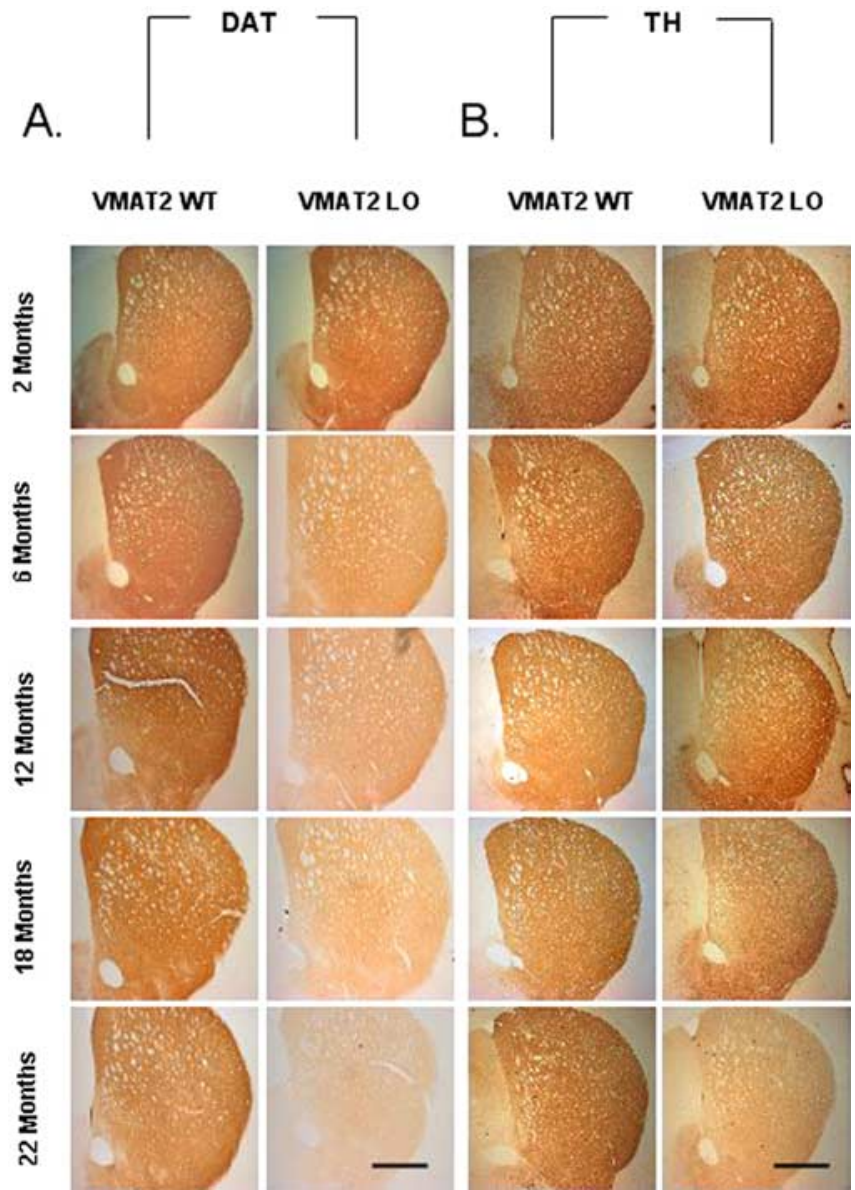

Figure 7. Immunohistochemical analysis of DAT and TH in striatum of aged mice. A, DAT immunoreactivity was reduced in VMAT2 LO mice at $6,12,18$, and 22 months of age, whereas TH immunoreactivity $(\boldsymbol{B})$ was reduced at 18 and 22 months of age. An analysis was performed on three to four animals per genotype at each age. Representative sections are shown. Scale bars, $300 \mu \mathrm{m}$.

observed. There were no alterations in DAT mRNA levels at 2, 6, 12 , or 18 months (data not shown).

No change in striatal TH protein expression was observed in the VMAT2 LO mice at 2, 6, or 12 months. In contrast, immunohistochemical assessment revealed an apparent decrease in striatal TH expression at 18 and 22 months (Fig. 6B). Additionally, reductions in striatal TH fiber density in the 18- and 22month-old VMAT2 LO mice was observed under high-power magnification (Fig. 9). Quantification of these reductions by immunoblotting demonstrated a $25 \%$ reduction at 18 months (Fig. $10 \mathrm{~B})$. Given the loss of TH protein expression in the striatum of older VMAT2 LO animals, quantification of $\mathrm{TH}$-positive $(\mathrm{TH}+)$ cells was performed on unilateral substantia nigra pars compacta (SNpc) of 2-, 18-, and 24-month-old VMAT2 WT and LO mice. A significant $12 \%$ loss in $\mathrm{TH}+$ cells was observed at 18 months, followed by a $26 \%$ loss in 24-month-old VMAT2 LO mice, compared with WT (Fig. 11A). To assess the possibility that the decline in $\mathrm{TH}+$ neurons was a result of downregulation of $\mathrm{TH}$, total cell counts were performed on Nissl-stained cells. A reduction in Nissl-stained cells was seen in VMAT2 LO mice at 18 months $(12 \%)$ and 24 months $(26 \%)$ (Fig. $11 B$ ). No change in the number of TH+ or Nissl-stained cells was observed between VMAT2 WT and LO at 2 months of age. In addition, no change was observed in TH + or Nissl cell number in the VMAT2 WT at 2, 18, and 24 months.

To further characterize the loss of $\mathrm{TH}+$ cell bodies in aged

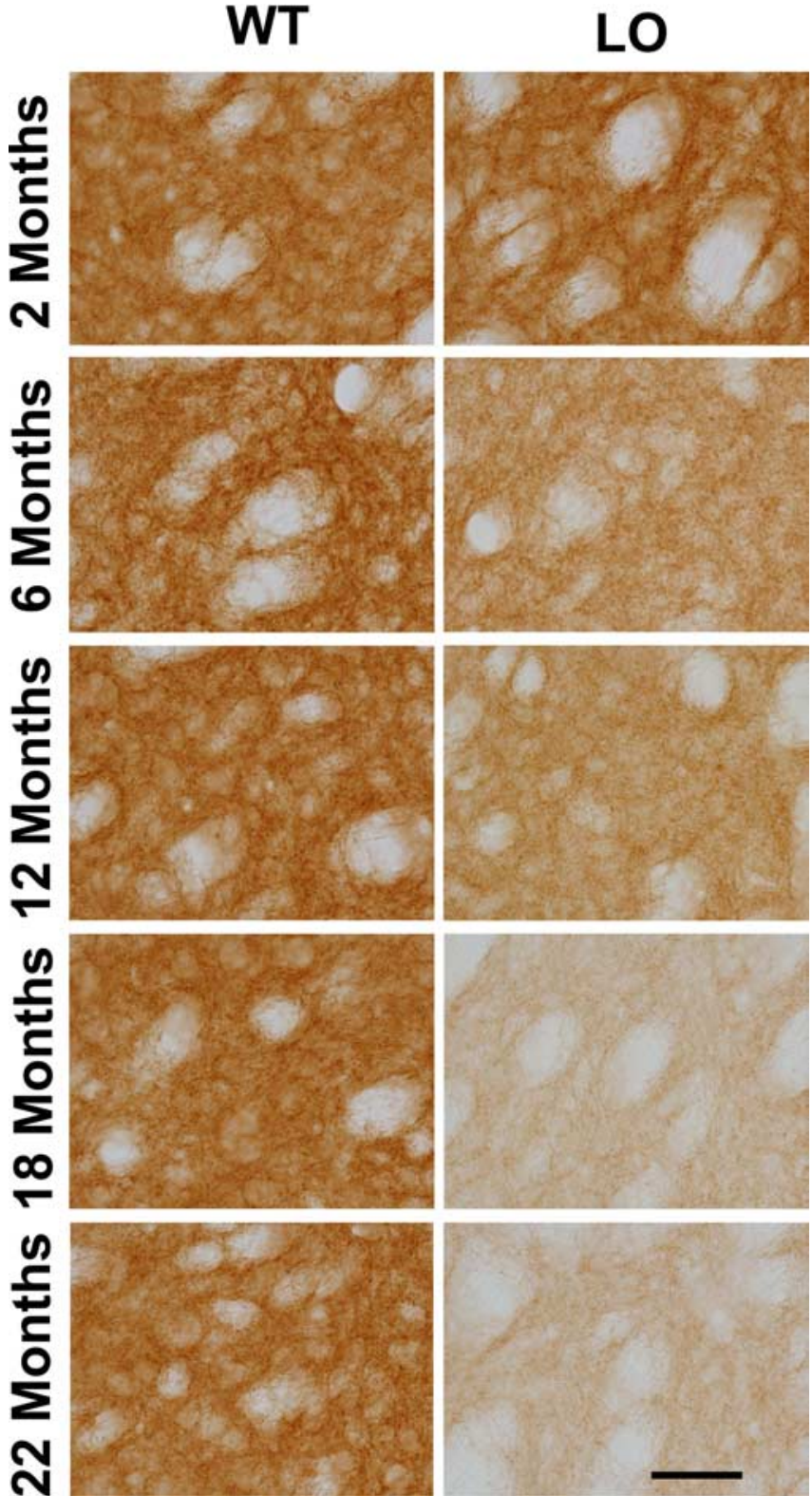

Figure 8. High-power magnification of DAT fiber density in the striatum of aged mice. High-power magnification $(40 \times)$ of DAT innervation in the striatum of aged VMAT2 mice shows a reduction in DAT immunoreactivity at 6 and 12 months, with an additional reduction in fiber density seen at 18 and 22 months. An analysis was performed on three to four animals per genotype at each age. Representative sections were taken from the middle region of the caudate-putamen and correspond to sections in Figure 7. Scale bar, $100 \mu \mathrm{m}$.

VMAT2 LO mice, tissue was processed for Fluoro-Jade B in the $\mathrm{SNpc}$, as well as the accumulation of silver deposition in the $\mathrm{SNpc}$. Fluoro-Jade B-positive neurons were observed in the SNpc of 22 month VMAT2 LO mice, compared with WT (Fig. 12A-D). As shown in Figure $12 \mathrm{~F}$, an increase in silver deposits was seen in the SNpc of 22-month-old VMAT2 LO mice, compared with WT. The accumulation of silver deposits was not seen in the SNpc of 2-month-old WT or LO mice (data not shown).

Accumulation of $\alpha$-synuclein is associated with Parkinson's disease (Goedert, 2001). We performed immunohistochemistry on midbrain sections from 18- and 22-month-old VMAT2 WT and LO mice and found increased $\alpha$-synuclein immunoreactivity and accumulation in SNpc (A9) neurons (Fig. 13 B,D). 
WT
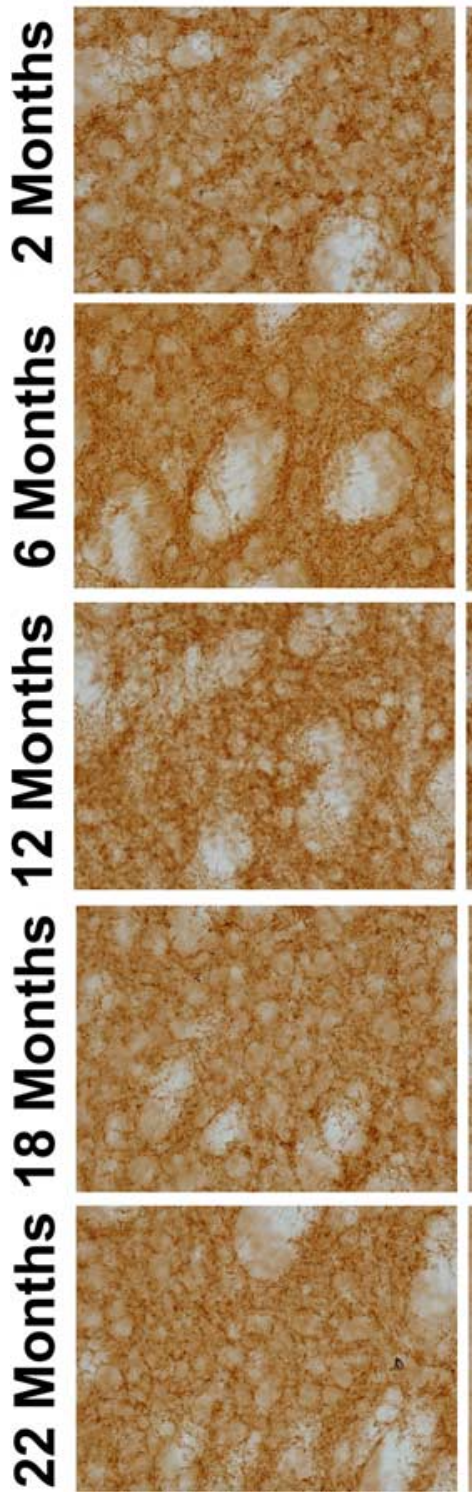

Figure 9. High-power magnification of TH fiber density in the striatum of aged mice. Highpower magnification ( $40 \times$ ) of TH immunoreactivity in the striatum of aged VMAT2 mice shows a reduction of TH fiber density at 18 and 22 months of age compared with WT. Analysis performed on three to four animals per genotype at each age. Representative sections were taken from the middle region of the caudate-putamen and correspond to sections in Figure 7. Scale bar, $100 \mu \mathrm{m}$.

\section{Discussion}

Mishandling of dopamine has been suggested to participate in the dopamine neurodegeneration that underlies PD (Graham, 1978; Hastings et al., 1996a,b; Montine et al., 1997; Miller et al., 1999a; Spencer et al., 2002). However, whereas several cellular models have shown that intracellular dopamine can cause damage (Montine et al., 1997; Berman and Hastings, 1999), this has never been demonstrated in vivo. Here, we report that disruption of dopamine storage by reduction of VMAT2 expression leads to an agedependent degeneration of nigrostriatal dopamine neurons.

Our results, which are summarized in Table 1, show that mice with reduced vesicular storage of dopamine exhibit an ageassociated decrease in striatal dopamine, accompanied by an increase in cysteinyl adducts of dopamine metabolites, as well as oxi-
A.

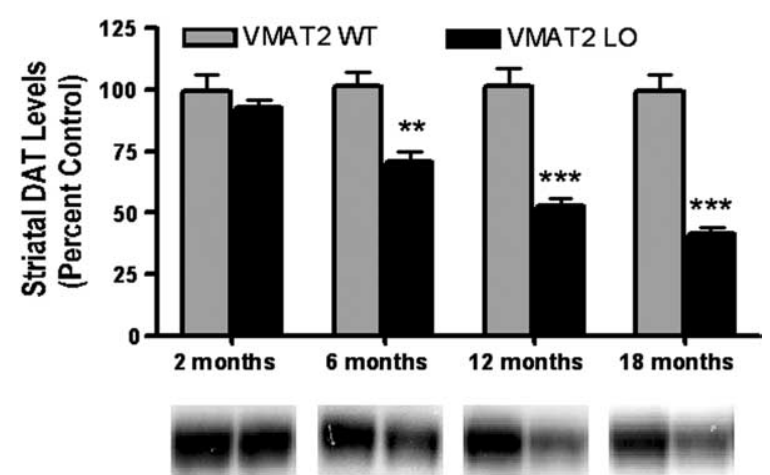

B.

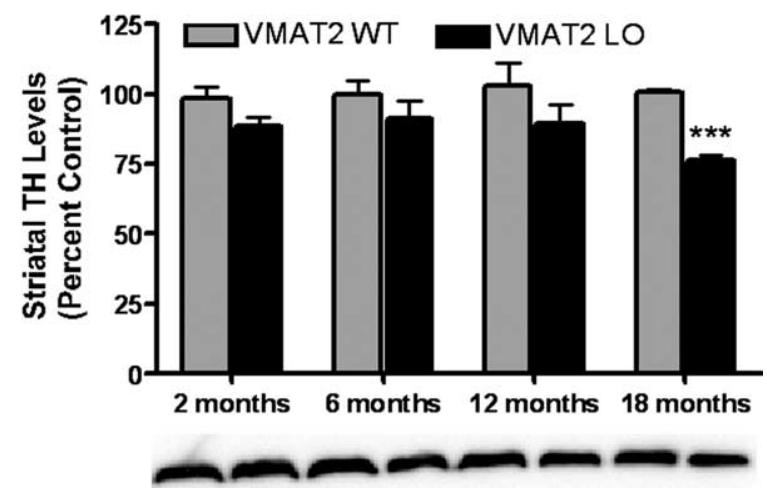

Figure 10. Immunoblotting analysis of DAT and TH in striatum of aged mice. $A$, Western blot analysis of striatal synaptosomes from VMAT2 WT and L0 mice show an age-dependent reduction in DAT expression in L0 mice beginning at 6 months of age. $\boldsymbol{B}$, Western blot analysis of striatal synaptosomes from VMAT2 WT and $L 0$ mice show a reduced expression of TH in VMAT2 L0 mice at 18 months of age. Columns represent percentage change from control. Results represent the mean \pm SEM for four animals per genotype at each age. ${ }^{* *} p<0.01 ;{ }^{* * *} p<$ 0.001 .

dative stress. Because these animals age, DAT protein levels and function are reduced. In contrast, the expression of tyrosine hydroxylase remains unchanged until mice reach 18 months of age. Furthermore, a significant and progressive loss of $\mathrm{TH}$-positive neurons was observed, as well as an increase in silver deposits in the substantia nigra, suggesting degeneration of this region. Finally, aged VMAT2 LO mice show pathological accumulations of $\alpha$-synuclein in the substantia nigra. These data demonstrate that reduced vesicular storage of dopamine is sufficient to cause neurodegeneration similar to that seen in Parkinson's disease.

Genetic and pharmacological reductions of VMAT2 result in lower tissue levels of striatal dopamine (Fon et al., 1997; Takahashi et al., 1997; Wang et al., 1997; Mooslehner et al., 2001). Consistent with previous reports, analysis of dopamine in our VMAT2 transgenic animals showed significantly reduced striatal dopamine levels (Fig. 1D), as well as DOPAC and HVA (data not shown). Striatal dopamine levels remain unchanged in the VMAT2 WT mice up to 12 months of age. In contrast, dopamine levels continue to decline in the aged VMAT2 LO animals, as seen previously in VMAT2 LO mice that are $\alpha$-synuclein null (Colebrooke et al., 2006) (Fig. 1E). These reductions are accompanied by an increase in the ratios of dopamine metabolites to dopamine in the aged VMAT2 LO mice (Fig. $2 A, B$ ), suggesting an increase in dopamine turnover (Zigmond et al., 2002). This increase appears to be a result of the age-dependent loss of striatal dopamine, in that the levels of DOPAC and HVA remain unchanged in the aged VMAT2 LO mice. Furthermore, the synthesis rate of dopamine is significantly elevated in the VMAT2 LO 
A.

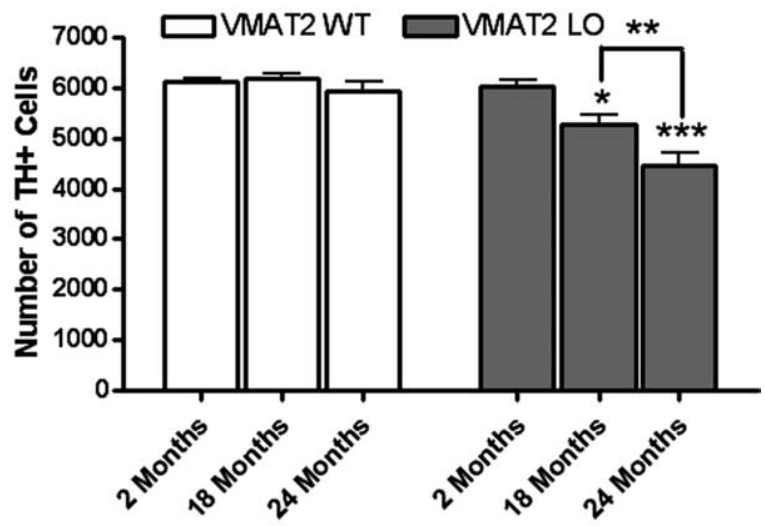

B.

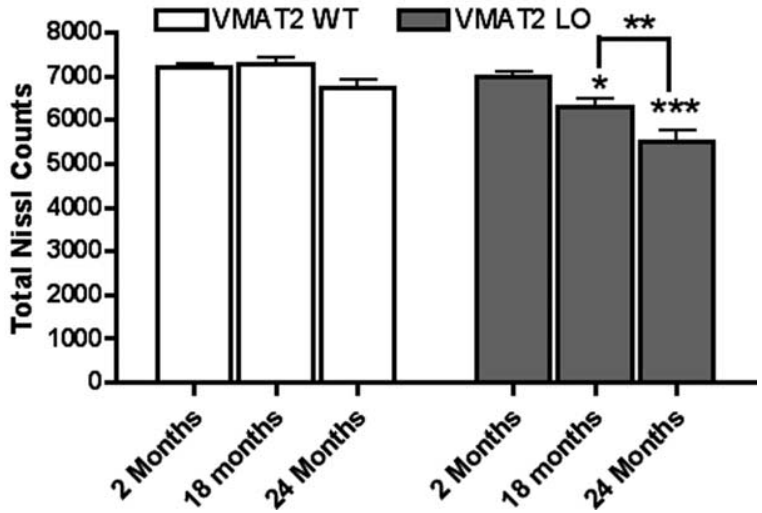

Figure 11. TH + and Nissl cell counts in the substantia nigra of 2, 18, and 24 month VMAT2 WT and $\mathrm{LO}$ mice. A significant reduction in TH + cells was observed in the 18-month-old VMAT2 LO mice compared with WT (VMAT2 WT, $6193 \pm 88.1$; VMAT2 L0, $5291 \pm 164.0 ; p<0.002$ ). In addition, a greater reduction in TH + cells was seen in 24-month-old VMAT2 $\mathrm{L} 0$ mice compared with WT (VMAT2 WT, $5951 \pm 205.2$; VMAT2 L0, $4468 \pm 185.7 ; p<0.002$ ). Furthermore, a significant reduction in Nissl cells was seen at 18 months (VMAT2 WT, $7307 \pm 111$; VMAT2 L0, $6312 \pm 166 ; p<0.005$ ) and 24 months (VMAT2 WT, $6746 \pm 135.4$; VMAT2 L0, $5500 \pm 210.1 ; p<0.005)$ between VMAT2 WT and L0 mice. Results represent the mean \pm SEM for three animals per genotype at each age. ${ }^{*} p<0.05 ;{ }^{* *} p<0.01 ;{ }^{* * *} p<0.001$.

mice compared with control (Fig. $1 F)$, similar to that seen in mice after administration of the VMAT2 inhibitor, reserpine (German et al., 1981). L-DOPA responsive motor deficits, such as rigidity and bradykinesia, are hallmark features seen in PD and are primarily associated with loss of dopamine in the nigrostriatal system (Olanow and Tatton, 1999). As in human PD patients, our VMAT2 LO mice exhibit significantly reduced locomotor activity (Fig. 3A) as a consequence of their decreased levels of dopamine and these deficits were abolished after administration of L-DOPA (Fig. 3B). Similar dopaminergic defects have been demonstrated in aged VMAT2 LO mice on an $\alpha$-synuclein null background (Colebrooke et al., 2006).

Cytosolic accumulation of dopamine and subsequent breakdown leads to the generation of reactive oxygen species, as well as highly reactive quinones (Graham, 1978; Montine et al., 1997), which may contribute to the pathophysiology of PD (Hastings et al., 1996b; Montine et al., 1997; Jenner, 2003). VMAT2 LO mice demonstrate an increase in free cysteinyl-DOPAC as well as cysteinyl-DOPA, both of which have been shown to be neurotoxic to dopamine neurons (Fig. 4A,B) (Graham, 1978; Montine et al., 1997). Similar accumulations of these adducts are seen in
VMAT2 WT
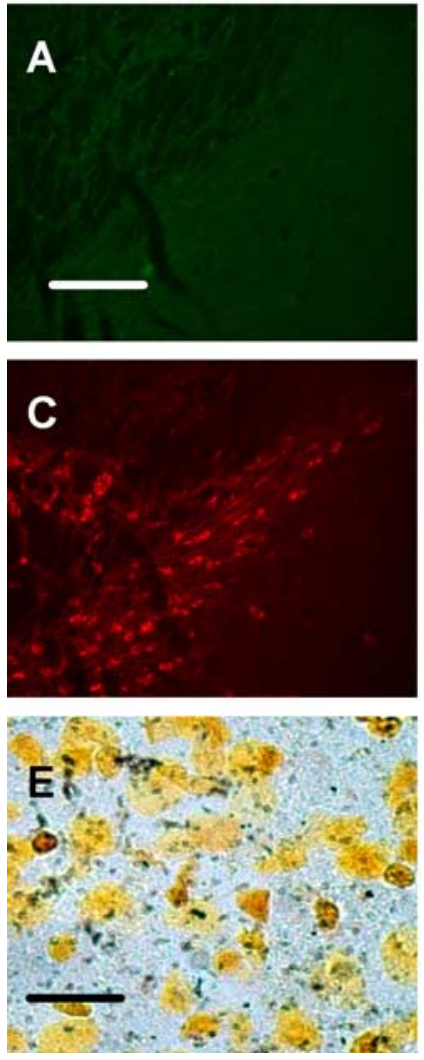

VMAT2 LO
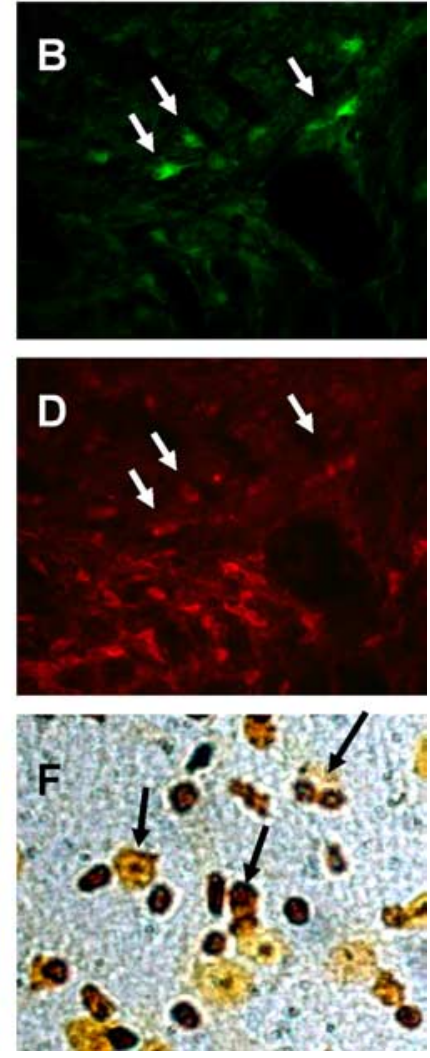

Figure 12. Determination of neuronal degeneration in aged VMAT2 LO mice. A, Fluoro-Jade B staining in 22-month-old VMAT2 WT mice. $\boldsymbol{B}$, Fluoro-Jade B-positive neurons in the SNpc of 22-month-old VMAT2 LO mice. C, Corresponding TH staining. Note the lack of Fluoro-Jade immunoreactivity in $\boldsymbol{A}$. D, Corresponding TH-immunoreactive neurons. Arrows denote neurons that are positive for Fluoro-Jade $(\boldsymbol{B}, \boldsymbol{D})$. Accumulation of silver deposits in SNpc of 22-month-old VMAT2 WT $(\boldsymbol{E})$ and $\mathrm{LO}(\boldsymbol{F})$ mice. Arrows indicate silver grain deposition in degenerating neurons. Analysis was performed on thee to four animals per genotype. Representative sections are shown. Scale bars, $100 \mu \mathrm{m}$.

the striatum of guinea pigs after pharmacological inhibition of VMAT2 by reserpine (Fornstedt-Wallin and Bergh, 1995). We were unable to detect the formation of cysteinyl-dopamine adducts. A plausible explanation for the absence of these adducts is most likely caused by the significantly depressed levels of dopamine present in the VMAT2 LO mice and the increased levels of cysteinyl metabolites. Examination of oxidative stress in the VMAT2 LO mice found an increase in protein carbonyl, as well as 3 -nitrotyrosine, formation in the striatum (Fig. $5 A, B$ ). Interestingly, these increases were not seen in the 2 or 6 month VMAT2 LO animals. Both markers have been shown to be elevated in PD patients (Alam et al., 1997; Good et al., 1998). The lack of change in these oxidative stress markers at the earlier time points could be attributable to the antioxidant system being able to effectively compensate for the increasingly oxidative environment resulting from the accumulation of cytosolic dopamine. Over time, it is possible that these defense systems were overwhelmed allowing oxidative damage to occur. In this regard, it has been well established that several of the antioxidant defense mechanisms used by the nigrostriatal dopamine system are impaired in PD patients, such as GSH, SOD, and catalase (Ambani et al., 1975; Perry et al., 1982; Marttila et al., 1988; Sofic et al., 1992; Sian et al., 1994; Samiec et al., 1998). Interestingly, GSH and MnSOD levels in the striatum of aged VMAT2 LO mice were reduced (Fig. 6B, C). 


\section{VMAT2 WT VMAT2 LO}

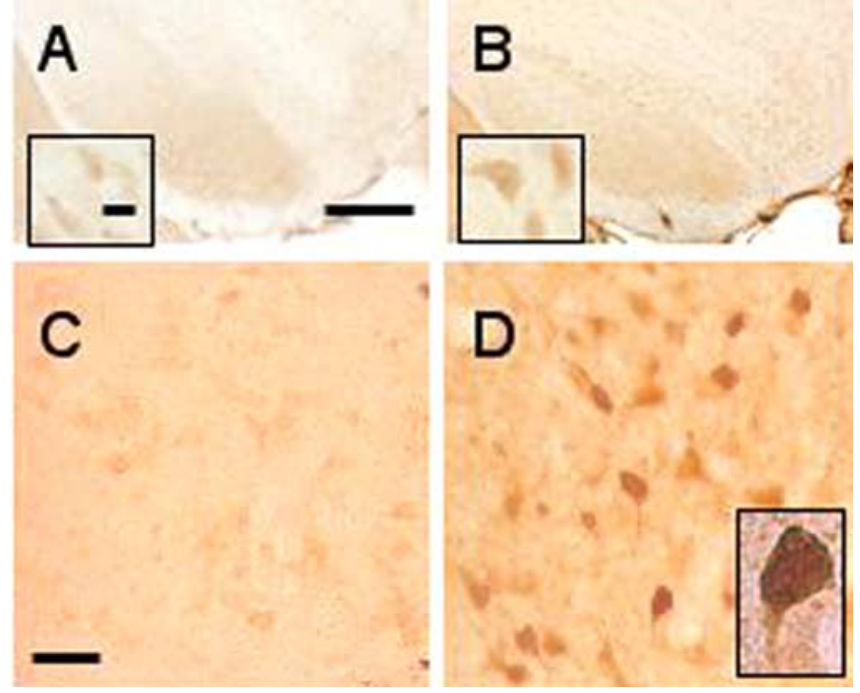

Figure 13. Synuclein neuropathology in aged VMAT2 LO mice. $\boldsymbol{A}, \boldsymbol{B}$, An increase in $\alpha$-synuclein immunoreactivity in the SNpc was seen in the VMAT2 L0 mice compared with WT at 18 months of age. $\boldsymbol{C}, \boldsymbol{D}$, An increased accumulation of $\alpha$-synuclein was seen in 22-month-old VMAT2 LO SNpc compared with WT. Analysis was performed on three to four animals per genotype. Representative sections are shown. Scale bars: $300 \mu \mathrm{m}$; inset, $20 \mu \mathrm{m}$.

These reductions provide additional evidence of increased oxidative stress in this model.

To further elucidate the effects of VMAT2 reduction in aged mice, we examined other presynaptic markers of the dopamine system. One such marker, the dopamine transporter, is especially important as a marker of progressive damage to the striatal dopamine terminals in PD (Miller et al., 1997). Interestingly, singlephoton emission tomography imaging is able to detect changes in DAT before the appearance of PD symptoms (Chalon et al., 1999; Prunier et al., 2003) and may be considered an antecedent for future damage to the nigrostriatal dopamine system. VMAT2 WT mice showed similar levels of DAT expression and function as they aged (Figs. $7 A, 10 A$ ). In contrast, striatal DAT function and expression were decreased in an age-dependent manner in the VMAT2 LO mice, which is reflective of the dying back hypothesis of $\mathrm{PD}$ where dopaminergic damage begins in the striatal terminal before reaching the cell body in the substantia nigra. Examination of DAT fiber immunoreactivity using high-power magnification in VMAT2 LO mice at each age suggests a reduction in DAT immunoreactivity without a loss of fiber density until they reach 18 and 22 months of age (Fig. 8). Interestingly, DAT mRNA levels in the midbrain were unchanged at the given time points (data not shown). Additionally, no change was seen in striatal TH levels in the aged VMAT2 LO animals until they reached 18 months of age (Figs. $7 \mathrm{~B}, 10 \mathrm{~B}$ ). In addition, a reduction in $\mathrm{TH}$ fiber density is also seen in the 18- and 22-month-old VMAT2 LO mice, providing additional evidence for the loss of $\mathrm{TH}$-positive nerve terminals in the striatum of these animals (Fig. 9). This suggests that the reductions in DAT expression and function are not a result of alterations in the production of DAT in the midbrain. We have shown previously similar results after exposure to neurotoxic polychlorinated biphenyls (PCB) (Caudle et al., 2006), which have been linked to increased risk for PD (Steenland et al., 2006). Studies have demonstrated the ability of dopamine quinones, as well as reactive oxygen species, to interact with
DAT, resulting in its alteration of expression and function, which may explain the decrease in DAT observed here (Berman et al., 1996; Whitehead et al., 2001).

In addition to the $>80 \%$ reduction of striatal dopamine, the loss of tyrosine hydroxylase-containing neurons in the SNpc is another hallmark feature of PD (Olanow and Tatton, 1999). Although no change was observed in the number of TH-positive (TH+) or Nisslstained cells in the SNpc of 2-month-old WT and LO mice, a significant loss of neurons was observed in the LO mice at 18 and 24 months (Fig. $11 A, B$ ). In addition, no difference in the number of $\mathrm{TH}+$ or Nissl-stained cells was seen between WT at any time point (Fig. $11 A, B$ ), suggesting that the loss of $\mathrm{TH}+$ neurons in the $\mathrm{LO}$ mice at 18 and 24 months is not caused by general aging. Interestingly, the amount of cell loss seen in the 18 and 24 month LO mice was similar regardless of whether $\mathrm{TH}+$ or Nissl-stained cells were counted (Fig. 11A,B). This suggests that the decline in $\mathrm{TH}+$ neurons in the SNpc of 18 and 24 month LO mice is specific to dopamine neurons. Fluoro-Jade B and silver staining have been used extensively as indicators of degenerating neurons in several animal models of dopamine cell death (Schmued et al., 1997; Betarbet et al., 2000; Manning-Bog et al., 2002; McCormack et al., 2002). We observed an increase in Fluoro-Jade-positive neurons in the VMAT2 LO mice, as well as deposition of silver granules in the SNpc at 22 months (Fig. $12 A-F)$.

Accumulation of the ubiquitous protein $\alpha$-synuclein has been shown to be a major component of Lewy bodies, a neuropathological hallmark of PD (Goedert et al., 1998). The association between $\alpha$-synuclein expression and neurodegeneration has been demonstrated extensively in several lines of $\alpha$-synuclein transgenic animals (Feany and Bender, 2000; Masliah et al., 2000; Rochet et al., 2000; van der Putten et al., 2000; Giasson et al., 2002; Lee et al., 2002). Immunohistochemical analysis of $\alpha$-synuclein pathology in the VMAT2 LO mice found an increase in $\alpha$-synuclein accumulation in neuronal cell bodies in the SNpc (Fig. $13 B, D$ ). We propose that the increased immunoreactivity and accumulation of $\alpha$-synuclein in the VMAT2 LO mice is a result of the ability of oxidized metabolites of dopamine to promote $\alpha$-synuclein pathology (Conway et al., 2001; Norris et al., 2005). Indeed, the interaction between $\alpha$-synuclein and dopamine-derived oxidative species in our VMAT2 LO mice may be the fundamental reason for the neurodegeneration we observed. This is supported by the fact that no loss of TH+ cells was seen in 24-month-old VMAT2 LO mice on a null $\alpha$-synuclein background (Colebrooke et al., 2006).

Our data indicate that mishandling of dopamine causes dopamine terminal dysfunction, increases in oxidative damage, and eventual neurodegeneration of the nigrostriatal dopamine system. The various neurochemical, behavioral, and pathological manifestations are summarized in Table 1. The pattern of progression, from the dopamine terminals to the cell body, may be representative of the process that occurs in idiopathic PD. For example, decreased DAT expression, which is seen early in PD pathogenesis may be a compensatory neurochemical manifestation that precedes the actual loss of dopamine neurons. Whether or not this observation identifies a potential therapeutic window to halt disease progression is not clear, but it does appear that profound neurochemical alterations can precede nigral dopamine neuron death. Additionally, the combination of progressive dopamine terminal loss, $\alpha$-synuclein accumulation, nigral degeneration, and L-DOPA responsive behavioral deficits make the VMAT2 LO mice an excellent model of Parkinson's disease.

We propose that altered dopamine homeostasis, as seen with reduced VMAT2, creates an environment that is permissive for 
Table 1. Summary of age-associated changes in VMAT2 LO mice

\begin{tabular}{|c|c|c|c|c|c|}
\hline Measured parameters & 2 months & 6 months & 12 months & 18 months & 22 months \\
\hline Striatal VMAT2 immunoblot & $\downarrow 95 \%$ & nd & nd & nd & nd \\
\hline Vesicular $\left[{ }^{3} \mathrm{H}\right] \mathrm{DA}$ uptake & $\downarrow 75 \%$ & nd & nd & nd & nd \\
\hline Striatal dopamine & $\downarrow 85 \%$ & $\downarrow 95 \%$ & $\downarrow 98 \%$ & nd & nd \\
\hline TH synthesis & $\uparrow 25 \%$ & $\uparrow 25 \%$ & $\uparrow 25 \%$ & nd & nd \\
\hline DOPAC/DA ratio & $\uparrow 300 \%$ & $\uparrow 800 \%$ & $\uparrow 1300 \%$ & nd & nd \\
\hline HVA/DA ratio & $\uparrow 525 \%$ & $\uparrow 575 \%$ & $\uparrow 1150 \%$ & nd & nd \\
\hline Cysteinyl-DOPA & $\uparrow 322 \%$ & nd & $\uparrow 316 \%$ & nd & nd \\
\hline Cysteinyl-DOPAC & $\uparrow 100 \%$ & nd & $\uparrow 100 \%$ & nd & nd \\
\hline Protein carbonyls & $\leftrightarrow$ & $\leftrightarrow$ & $\uparrow 50 \%$ & $\uparrow 45 \%$ & nd \\
\hline 3-Nitrotyrosine & $\leftrightarrow$ & $\leftrightarrow$ & $\uparrow 150 \%$ & $\uparrow 140 \%$ & nd \\
\hline Striatal DAT immunoblot & $\leftrightarrow$ & $\downarrow 30 \%$ & $\downarrow 54 \%$ & $\downarrow 60 \%$ & nd \\
\hline$\left[{ }^{3} \mathrm{H}\right]$ WIN 35,428 binding & $\downarrow 30 \%$ & $\downarrow 52 \%$ & $\downarrow 62 \%$ & nd & nd \\
\hline$\left[{ }^{3} \mathrm{H}\right]$ Dopamine uptake & $\downarrow 34 \%$ & $\downarrow 57 \%$ & $\downarrow 66 \%$ & nd & nd \\
\hline Striatal TH immunoblot & $\leftrightarrow$ & $\leftrightarrow$ & $\leftrightarrow$ & $\downarrow 25 \%$ & nd \\
\hline Locomotion & $\downarrow 40 \%$ & $\downarrow 40 \%$ & $\downarrow 40 \%$ & $\downarrow 65 \%$ & nd \\
\hline$\alpha$-Synuclein accumulation & $\leftrightarrow$ & nd & nd & nd & $\uparrow$ \\
\hline $\mathrm{TH}+$ cell counts (SNpc) & $\leftrightarrow$ & nd & nd & $\downarrow 12 \%$ & $\downarrow 26 \%^{a}$ \\
\hline Neuronal degeneration ${ }^{b}$ & No & nd & nd & nd & Yes \\
\hline
\end{tabular}

nd, Not determined.

${ }^{a}$ Performed on 24-month-old mice.

${ }^{b}$ Fluoro-Jade and silver staining.

PD-related cellular damage. It is possible that PD pathogenesis represents a state of altered dopamine homeostasis in the presence of other factors, such as PD-related genes or environmental agents. Therefore, crossing the VMAT2 LO mice with mice transgenic for various $\mathrm{PD}$ mutations or exposing them to PD-related toxicants may accelerate the observed pathogenesis and more accurately reflect the multifactorial nature of Parkinson's disease.

\section{References}

Alam ZI, Daniel SE, Lees AJ, Marsden DC, Jenner P, Halliwell B (1997) A generalised increase in protein carbonyls in the brain in Parkinson's but not incidental Lewy body disease. J Neurochem 69:1326-1329.

Ambani LM, Van Woert MH, Murphy S (1975) Brain peroxidase and catalase in Parkinson disease. Arch Neurol 32:114-118.

Berman SB, Hastings TG (1999) Dopamine oxidation alters mitochondrial respiration and induces permeability transition in brain mitochondria: implications for Parkinson's disease. J Neurochem 73:1127-1137.

Berman SB, Zigmond MJ, Hastings TG (1996) Modification of dopamine transporter function: effect of reactive oxygen species and dopamine. J Neurochem 67:593-600.

Betarbet R, Sherer TB, MacKenzie G, Garcia-Osuna M, Panov AV, Greenamyre JT (2000) Chronic systemic pesticide exposure reproduces features of Parkinson's disease. Nat Neurosci 3:1301-1306.

Bradford MM (1976) A rapid and sensitive method for the quantitation of microgram quantities of protein utilizing the principle of protein-dye binding. Anal Biochem 72:248-254.

Carlsson A, Davis JN, Kehr W, Lindqvist M, Atack CV (1972) Simultaneous measurement of tyrosine and tryptophan hydroxylase activities in brain in vivo using an inhibitor of the aromatic amino acid decarboxylase. Naunyn Schmiedebergs Arch Pharmacol 275:153-168.

Caudle WM, Richardson JR, Delea KC, Guillot TS, Wang M, Pennell KD, Miller GW (2006) Polychlorinated biphenyl-induced reduction of dopamine transporter expression as a precursor to Parkinson's diseaseassociated dopamine toxicity. Toxicol Sci 92:490-499.

Chalon S, Emond P, Bodard S, Vilar MP, Thiercelin C, Besnard JC, Guilloteau D (1999) Time course of changes in striatal dopamine transporters and D2 receptors with specific iodinated markers in a rat model of Parkinson's disease. Synapse 31:134-139.

Chan P, Di Monte DA, Langston JW, Janson AM (1997) (+)MK-801 does not prevent MPTP-induced loss of nigral neurons in mice. J Pharmacol Exp Ther 280:439-446.

Colebrooke RE, Humby T, Lynch PJ, McGowan DP, Xia J, Emson PC (2006) Age-related decline in striatal dopamine content and motor performance occurs in the absence of nigral cell loss in a genetic mouse model of Parkinson's disease. Eur J Neurosci 24:2622-2630.
Conway KA, Rochet JC, Bieganski RM, Lansbury Jr PT (2001) Kinetic stabilization of the alpha-synuclein protofibril by a dopamine-alphasynuclein adduct. Science 294:1346-1349.

Erickson JD, Eiden LE, Hoffman BJ (1992) Expression cloning of a reserpine-sensitive vesicular monoamine transporter. Proc Natl Acad Sci USA 89:10993-10997.

Feany MB, Bender WW (2000) A Drosophila model of Parkinson's disease. Nature 404:394-398.

Fon EA, Pothos EN, Sun BC, Killeen N, Sulzer D, Edwards RH (1997) Vesicular transport regulates monoamine storage and release but is not essential for amphetamine action. Neuron 19:1271-1283.

Fornstedt-Wallin B, Bergh I (1995) Sensitive high-performance liquid chromatographic method for the determination of 5-S-cysteinyldopamine, 5-Scysteinyl-3,4-dihydroxyphenylacetic acid and 5-S-cysteinyl-3,4-dihydroxyphenylalanine. J Chromatogr B Biomed Appl 663:9-14.

Fumagalli F, Gainetdinov RR, Wang YM, Valenzano KJ, Miller GW, Caron MG (1999) Increased methamphetamine neurotoxicity in heterozygous vesicular monoamine transporter 2 knock-out mice. J Neurosci 19:2424-2431.

Gainetdinov RR, Fumagalli F, Wang YM, Jones SR, Levey AI, Miller GW, Caron MG (1998) Increased MPTP neurotoxicity in vesicular monoamine transporter 2 heterozygote knockout mice. J Neurochem 70:1973-1978.

German DC, McMillen BA, Sanghera MK, Saffer SI, Shore PA (1981) Effects of severe dopamine depletion on dopamine neuronal impulse flow and on tyrosine hydroxylase regulation. Brain Res Bull 6:131-134.

Giasson BI, Duda JE, Quinn SM, Zhang B, Trojanowski JQ, Lee VM (2002) Neuronal alpha-synucleinopathy with severe movement disorder in mice expressing A53T human alpha-synuclein. Neuron 34:521-533.

Glatt C, Almonte M, Taylor T, Edwards RH, Freimer N, Tanner C (2006) Structural variants in the vesicular monoamine transporter do not contribute to sporadic Parkinson's disease. Mov Disord 21:426-427.

Goedert M (2001) Alpha-synuclein and neurodegenerative diseases. Nat Rev Neurosci 2:492-501.

Goedert M, Jakes R, Crowther RA, Hasegawa M, Smith MJ, Spillantini MG (1998) Intraneuronal filamentous tau protein and alpha-synuclein deposits in neurodegenerative diseases. Biochem Soc Trans 26:463-471.

Good PF, Hsu A, Werner P, Perl DP, Olanow CW (1998) Protein nitration in Parkinson's disease. J Neuropathol Exp Neurol 57:338-342.

Graham DG (1978) Oxidative pathways for catecholamines in the genesis of neuromelanin and cytotoxic quinones. Mol Pharmacol 14:633-643.

Hastings TG, Zigmond MJ (1997) Loss of dopaminergic neurons in parkinsonism: possible role of reactive dopamine metabolites. J Neural Transm Suppl 49:103-110.

Hastings TG, Lewis DA, Zigmond MJ (1996a) Role of oxidation in the neurotoxic effects of intrastriatal dopamine injections. Proc Natl Acad Sci USA 93:1956-1961. 
Hastings TG, Lewis DA, Zigmond MJ (1996b) Reactive dopamine metabolites and neurotoxicity: implications for Parkinson's disease. Adv Exp Med Biol 387:97-106.

Jenner P (2003) Oxidative stress in Parkinson's disease. Ann Neurol 53: S26-S36; discussion S36-S38.

Jones DP (2002) Redox potential of GSH/GSSG couple: assay and biological significance. Methods Enzymol 348:93-112.

Jones DP, Go YM, Anderson CL, Ziegler TR, Kinkade Jr JM, Kirlin WG (2004) Cysteine/cystine couple is a newly recognized node in the circuitry for biologic redox signaling and control. FASEB J 18:1246-1248.

Jones SR, Joseph JD, Barak LS, Caron MG, Wightman RM (1999) Dopamine neuronal transport kinetics and effects of amphetamine. J Neurochem 73:2406-2414.

Lee J, Koh D, Andijani M, Saw SM, Munoz C, Chia SE, Wong ML, Hong CY, Ong CN (2002) Effluents from a pulp and paper mill: a skin and health survey of children living in upstream and downstream villages. Occup Environ Med 59:373-379.

Liu Y, Edwards RH (1997) The role of vesicular transport proteins in synaptic transmission and neural degeneration. Annu Rev Neurosci 20:125-156.

Liu Y, Roghani A, Edwards RH (1992a) Gene transfer of a reserpinesensitive mechanism of resistance to $N$-methyl-4-phenylpyridinium. Proc Natl Acad Sci USA 89:9074-9078.

Liu Y, Peter D, Roghani A, Schuldiner S, Prive GG, Eisenberg D, Brecha N, Edwards RH (1992b) A cDNA that suppresses MPP + toxicity encodes a vesicular amine transporter. Cell 70:539-551.

Manning-Bog AB, McCormack AL, Li J, Uversky VN, Fink AL, Di Monte DA (2002) The herbicide paraquat causes up-regulation and aggregation of alpha-synuclein in mice: paraquat and alpha-synuclein. J Biol Chem 277:1641-1644.

Marttila RJ, Lorentz H, Rinne UK (1988) Oxygen toxicity protecting enzymes in Parkinson's disease. Increase of superoxide dismutase-like activity in the substantia nigra and basal nucleus. J Neurol Sci 86:321-331.

Masliah E, Rockenstein E, Veinbergs I, Mallory M, Hashimoto M, Takeda A, Sagara Y, Sisk A, Mucke L (2000) Dopaminergic loss and inclusion body formation in alpha-synuclein mice: implications for neurodegenerative disorders. Science 287:1265-1269.

McCormack AL, Thiruchelvam M, Manning-Bog AB, Thiffault C, Langston JW, Cory-Slechta DA, Di Monte DA (2002) Environmental risk factors and Parkinson's disease: selective degeneration of nigral dopaminergic neurons caused by the herbicide paraquat. Neurobiol Dis 10:119-127.

Miller GW, Staley JK, Heilman CJ, Perez JT, Mash DC, Rye DB, Levey AI (1997) Immunochemical analysis of dopamine transporter protein in Parkinson's disease. Ann Neurol 41:530-539.

Miller GW, Gainetdinov RR, Levey AI, Caron MG (1999a) Dopamine transporters and neuronal injury. Trends Pharmacol Sci 20:424-429.

Miller GW, Erickson JD, Perez JT, Penland SN, Mash DC, Rye DB, Levey AI (1999b) Immunochemical analysis of vesicular monoamine transporter (VMAT2) protein in Parkinson's disease. Exp Neurol 156:138-148.

Montine TJ, Picklo MJ, Amarnath V, Whetsell Jr WO, Graham DG (1997) Neurotoxicity of endogenous cysteinylcatechols. Exp Neurol 148:26-33.

Mooslehner KA, Chan PM, Xu W, Liu L, Smadja C, Humby T, Allen ND, Wilkinson LS, Emson PC (2001) Mice with very low expression of the vesicular monoamine transporter 2 gene survive into adulthood: potential mouse model for parkinsonism. Mol Cell Biol 21:5321-5331.

Norris EH, Giasson BI, Hodara R, Xu S, Trojanowski JQ, Ischiropoulos H, Lee VM (2005) Reversible inhibition of alpha-synuclein fibrillization by dopaminochrome-mediated conformational alterations. J Biol Chem 280:21212-21219.

Olanow CW, Tatton WG (1999) Etiology and pathogenesis of Parkinson's disease. Annu Rev Neurosci 22:123-144.

Patel J, Mooslehner KA, Chan PM, Emson PC, Stamford JA (2003) Presynaptic control of striatal dopamine neurotransmission in adult vesicular monoamine transporter 2 (VMAT2) mutant mice. J Neurochem 85:898-910.

Perry TL, Godin DV, Hansen S (1982) Parkinson's disease: a disorder due to nigral glutathione deficiency? Neurosci Lett 33:305-310.

Prunier C, Payoux P, Guilloteau D, Chalon S, Giraudeau B, Majorel C, Tafani M, Bezard E, Esquerre JP, Baulieu JL (2003) Quantification of dopamine transporter by 123I-PE2I SPECT and the noninvasive Logan graphical method in Parkinson's disease. J Nucl Med 44:663-670.
Rabinovic AD, Lewis DA, Hastings TG (2000) Role of oxidative changes in the degeneration of dopamine terminals after injection of neurotoxic levels of dopamine. Neuroscience 101:67-76.

Reveron ME, Savelieva KV, Tillerson JL, McCormack AL, Di Monte DA, Miller GW (2002) L-DOPA does not cause neurotoxicity in VMAT2 heterozygote knockout mice. Neurotoxicology 23:611-619.

Richardson JR, Miller GW (2004) Acute exposure to aroclor 1016 or 1260 differentially affects dopamine transporter and vesicular monoamine transporter 2 levels. Toxicol Lett 148:29-40.

Rochet JC, Conway KA, Lansbury Jr PT (2000) Inhibition of fibrillization and accumulation of prefibrillar oligomers in mixtures of human and mouse alpha-synuclein. Biochemistry 39:10619-10626.

Samiec PS, Drews-Botsch C, Flagg EW, Kurtz JC, Sternberg Jr P, Reed RL, Jones DP (1998) Glutathione in human plasma: decline in association with aging, age-related macular degeneration, and diabetes. Free Radic Biol Med 24:699-704.

Schmued LC, Albertson C, Slikker Jr W (1997) Fluoro-Jade: a novel fluorochrome for the sensitive and reliable histochemical localization of neuronal degeneration. Brain Res 751:37-46.

Schuldiner S, Shirvan A, Linial M (1995) Vesicular neurotransmitter transporters: from bacteria to humans. Physiol Rev 75:369-392.

Sian J, Dexter DT, Lees AJ, Daniel S, Agid Y, Javoy-Agid F, Jenner P, Marsden CD (1994) Alterations in glutathione levels in Parkinson's disease and other neurodegenerative disorders affecting basal ganglia. Ann Neurol 36:348-355.

Sofic E, Lange KW, Jellinger K, Riederer P (1992) Reduced and oxidized glutathione in the substantia nigra of patients with Parkinson's disease. Neurosci Lett 142:128-130.

Specht CG, Schoepfer R (2001) Deletion of the alpha-synuclein locus in a subpopulation of C57BL/6J inbred mice. BMC Neurosci 2:11.

Spencer JP, Whiteman M, Jenner P, Halliwell B (2002) 5-s-Cysteinylconjugates of catecholamines induce cell damage, extensive DNA base modification and increases in caspase- 3 activity in neurons. J Neurochem 81:122-129.

Staal RG, Hogan KA, Liang CL, German DC, Sonsalla PK (2000) In vitro studies of striatal vesicles containing the vesicular monoamine transporter (VMAT2): rat versus mouse differences in sequestration of 1-methyl-4-phenylpyridinium. J Pharmacol Exp Ther 293:329-335.

Steenland K, Hein MJ, Cassinelli Jr RT, Prince MM, Nilsen NB, Whelan EA, Waters MA, Ruder AM, Schnorr TM (2006) Polychlorinated biphenyls and neurodegenerative disease mortality in an occupational cohort. Epidemiology 17:8-13.

Takahashi N, Miner LL, Sora I, Ujike H, Revay RS, Kostic V, Jackson-Lewis V, Przedborski S, Uhl GR (1997) VMAT2 knockout mice: heterozygotes display reduced amphetamine-conditioned reward, enhanced amphetamine locomotion, and enhanced MPTP toxicity. Proc Natl Acad Sci USA 94:9938-9943.

van der Putten H, Wiederhold KH, Probst A, Barbieri S, Mistl C, Danner S, Kauffmann S, Hofele K, Spooren WP, Ruegg MA, Lin S, Caroni P, Sommer B, Tolnay M, Bilbe G (2000) Neuropathology in mice expressing human $\alpha$-synuclein. J Neurosci 20:6021-6029.

Wang YM, Gainetdinov RR, Fumagalli F, Xu F, Jones SR, Bock CB, Miller GW, Wightman RM, Caron MG (1997) Knockout of the vesicular monoamine transporter 2 gene results in neonatal death and supersensitivity to cocaine and amphetamine. Neuron 19:1285-1296.

Watson WH, Chen Y, Jones DP (2003) Redox state of glutathione and thioredoxin in differentiation and apoptosis. BioFactors 17:307-314.

West MJ, Slomianka L, Gundersen HJ (1991) Unbiased stereological estimation of the total number of neurons in the subdivisions of the rat hippocampus using the optical fractionator. Anat Rec 231:482-497.

Whitehead RE, Ferrer JV, Javitch JA, Justice JB (2001) Reaction of oxidized dopamine with endogenous cysteine residues in the human dopamine transporter. J Neurochem 76:1242-1251.

Yelin R, Schuldiner S (1995) The pharmacological profile of the vesicular monoamine transporter resembles that of multidrug transporters. FEBS Lett 377:201-207.

Zigmond MJ, Hastings TG, Perez RG (2002) Increased dopamine turnover after partial loss of dopaminergic neurons: compensation or toxicity? Parkinsonism Relat Disord 8:389-393. 